\title{
La Historia y sus dobles: identidad y contrafactura histórica en la novela The plot against America de Philip Roth
}

\section{Daniel Del Percio ${ }^{1}$}

Universidad de Palermo.

\section{Tipo de trabajo: Artículo}

Material original autorizado para su primer publicación en el Journal de Ciencias Sociales, Revista Académica de la Facultad de Ciencias Sociales de la Universidad de Palermo.

Recibido: 7-7-2014

Aceptado: $10-9-2014$

\section{Resumen:}

La novela The plotagainstAmerica, de Philip Roth (2005) es una ucronía que, a través de la modificación de un acontecimiento puntual de la historia norteamericana (la no reelección para su tercer mandato del presidente Franklin Delano Roosevelt, y la hipotética consagración del republicano, aviador y aislacionista Charles Lindbergh en su lugar), proyecta la experiencia histórica de la persecución y de la supervivencia de la identidad de las minorías en un nada imposible escenario histórico totalitario en EE.UU. La estructura "as if" propia del género de la ucronía (término construido a partir del griego ou-cronos, "no tiempo", un tiempo "otro"), permite la convivencia del presente vinculado con el tiempo de la enunciación de la novela con "otro presente" paradójico, propio del tiempo de la enunciación, en donde el receptor de la novela se encuentra con una historia en donde han cambiado los personajes, los lugares y las fechas, pero los conflictos han permanecido esencialmente idénticos. Esta "historia contrafáctica" se complementa con el desarrollo de una "autobiografía ficcional" del propio autor, que se incluye en la novela junto con su constelación familiar, como "narrador homodiegético" o testigo de los acontecimientos que desarrollan en la ficción los grandes personajes históricos (Roosevelt, Lindbergh, von Ribbentrop, La Guardia, Ford). Metodológicamente, el análisis de esta novela implica su concepción como objeto de estudio complejo, interdisciplinario, al converger en él disciplinas como la literatura, la semiótica, la historia y la política.

Palabras Clave: Ucronía, Philip Roth, Identidad, Totalitarismo.

\footnotetext{
1 Doctor en Letras. Investigado y Docente en la Facultad de Ciencias Sociales, Universidad de Palermo. ddelpercio1@gmail.com
} 
Abstract: The novel The plot against America by Philip Roth (2005) is a ucronía that, through the modification of a single event in American History (no reelection for a third term of President Franklin Delano Roosevelt, and the consecration of the hypothetical Republican, aviator and isolationist Charles Lindbergh in place), projects the historical experience of persecution and survival of minority identity in a no impossible totalitarian historical scenario in U.S. Self "as if" structure ucronía genre (a term constructed from the Greek ou-chronos, "no time," a time "other"), allows the coexistence of this time linked to the enunciation of the novel with "other present" paradoxical own time of utterance, where the receiver of the novel finds a history where the characters, places and dates have changed, but conflicts have remained essentially identical. This "counterfactual history" is complemented by the development of a "fictional autobiography" of the author, which is included in the novel with his family constellation, as "homodiegetic narrator" or witness the events that develop in the great fiction characters Historic (Roosevelt, Lindbergh, von Ribbentrop, La Guardia, Ford). Methodologically, the analysis of this novel involves a complex object, interdisciplinary study, to converge on it disciplines such as literature, semiotics, history and politics.

Keywords: Ucrony, Philip Roth, Identity, Totalitarianism.

\section{Introducción: naturaleza y sentido de la ucronía}

Acaso lo más perturbador de la figura del doble no es su aparente identidad con el original, sino las mínimas, muchas veces insignificantes, asimetrías que lo diferencian de él. Asimetrías que ya estaban presentes, en la sombra, ocultas entonces, pero también, en sustancia, casi idénticas, y que transmiten un aire siniestro o, al menos, de profunda ambigüedad, a aquello que tenemos bajo la luz.

También la historia posee sus dobles, lo que podríamos denominar sus "dobles ficcionales", las historias "otras" que podrían haber sido, pero que no sucedieron. Parafraseando a Italo Calvino, una historia invisible construida con las "ramas secas del pasado", con aquello que no llegó a ser, pero que sin embargo, constituye una "ausencia presente", una posibilidad no realizada que puede tener mucho que decir del presente "real". Este es el caso de la novela The plot against America (La conjura contra América) del escritor norteamericano Philip Roth (2005), acaso más conocido por su novela Pastoral Americana, por la que obtuvo el premio Pulitzer en 1997. Hemos elegido esta obra en parte por su carácter más bien reciente (la primera edición en inglés es de 2004), pero también porque opera sobre aspectos epistemológicos muy profundos vinculados con la historia y la política en cuanto disciplinas científicas.

En efecto, acostumbrados a géneros como la novela histórica y a su documentación exhaustiva, de improviso nos encontramos aquí con una propuesta inquietante: en las elecciones presidenciales norteamericanas de 1941 Franklin Delano Roosevelt, el candidato del partido Demócrata, es derrotado por un inesperado candidato Republicano: el aviador y héroe americano Charles Lindbergh. Esta variación ficcional de la historia posee ramificaciones siniestras: Lindbergh, al menos en la visión de Roth, es un aliado del nazismo. Veremos más adelante en qué elementos históricos documentados se basa Roth para semejante hipótesis contrafáctica. 
Evidentemente, este tipo de ficciones requiere de una teoría específica. No es aplicable aquí el concepto de "novela histórica", ya que la ficción altera los hechos mismos, y no sólo a los personajes que se despliegan en ella. Tampoco sería lícito en este caso recurrir a teorías de lo fantástico, ya que en rigor esta alteración no tiene como elemento central un cuestionamiento ontológico, propio de la literatura fantástica, sino, como ya advertimos, fundamentalmente epistemológico².

Una primera cuestión para abordar teóricamente este problema es definir cuál es el concepto mismo de "narratividad" vinculado con este tipo de obras. Dicho de otro modo, qué implica este narrar. Para Greimas (Reis, 1995, p. 166), la narratividad es: "la irrupción de lo discontinuo en la permanencia discursiva de una vida, de una historia, de un individuo, de una cultura". Debemos entender lo discontinuo como todo hecho que produce una variación en la linealidad de la historia, tanto entendida colectiva como individualmente. No es menor el hecho de que esta discontinuidad se pueda producir en áreas aparentemente independientes como la vida (una vida), la historia o la cultura. Paul Ricoeur revisa esta idea, al considerar que es imposible explicar la narratividad al margen de la llamada semántica de la acción. Esto es

una fenomenología del sufrir-actuar, en la que adquieren sentido nociones como privación y donación. [...] existe entre la actividad de contar una historia y el carácter temporal de la experiencia humana una correlación que no es puramente accidental, pero presenta una forma de necesidad transcultural [considerando] a la temporalidad como esa estructura de la existencia que alcanza el lenguaje en la narratividad y la narratividad como la estructura del lenguaje que tiene en la temporalidad su referente fundamental. (Reis, 1995, pp. 170-171)

En esta fenomenología, lo que Ricoeur denomina "trama" o mythos (en el sentido aristotélico del término) se constituye en una "mediación" entre planos diversos. El concepto en sí de Ricouer es tan amplio y fructífero, que no podemos abarcarlo aquí en su totalidad, sino tan sólo en el sentido que aplicaremos en nuestro trabajo: el acto de narrar como una "mediación" para el conocimiento del sí mismo, entendido este "sí mismo" tanto en su carácter de identidad individual como colectiva, social ${ }^{3}$. En efecto, el ser "otro" a través de un personaje es la base de dicha mediación que, en definitiva, reconfigura la identidad 4 .

La mediación narrativa subraya, de ese modo, que una de las características del conocimiento de uno mismo consiste en ser una interpretación de sí. La apropiación de la identidad del personaje ficticio que lleva a cabo el lector es el vehículo privilegiado de esa interpretación. [...] apropiarse mediante la identificación de un personaje conlleva que uno mismo se someta al ejercicio de las variaciones imaginativas, que

\footnotetext{
2 No obstante, otras famosas obras que recurren a la historia contrafáctica, como The Man in the High Castle, de Philip Dick, (conocida en español como El Hombre en el Castillo) son de naturaleza fantástica. Esta novela posee un vínculo estrecho con la Teodicea de Leibniz.

3 Se trata de la teoría de la Triple Mimesis, que Ricoeur desarrolla en los tres volúmenes de Tiempo y Narración, particularmente en su primer tomo dedicado a la narratividad del discurso histórico (2007a). La aplicación completa de la teoría de Ricoeur al relato utópico la hemos desarrollado en otro trabajo (Del Percio, 2012).

4 El concepto de catharsis propio de la tragedia griega se basa precisamente en esta idea de "mediación": los personajes, al representar un papel, "median" para lograr la purgación de las penas y angustias de los espectadores, que tienen ante sí distintas facetas de un drama tanto individual como de la propia Polis.
} 
se convierten de ese modo en las propias variaciones del sí mismo. (Ricoeur, 1999, pp. 227-228)

Este concepto no sólo es aplicable sino que es fundamental para comprender las tres formas de ficción histórica más importantes: la novela histórica, la historia ficcional y la ucronía.

En la novela histórica, es esencial la presencia de personajes que actúen como "mediaciones" entre el receptor y la historia. Constituyen formas individuales de comprender los acontecimientos, que enriquecen la ubicación dentro de la historia que posee el individuo sobre sí mismo y sobre la sociedad de la que él forma parte.

Lo que podríamos denominar "historia ficcional", en cambio, opera sobre un tipo de discurso esencialmente científico: desde esta perspectiva, la narrativa de la ciencia histórica debería pensarse, también, como una estructura que incluye elementos ficcionales, en cuanto a su capacidad de proyectar futuros posibles en el tiempo. Este rasgo ficcional de la historia ha sido aprovechado tanto desde la ciencia histórica como desde la literatura. En el primer caso, el concepto de "historia virtual" elaborado por Niall Ferguson (Ferguson, 1998, pp. 77-86) se basa en someter los sucesos históricos a la pregunta "qué hubiera pasado si", en donde el condicional determina un cambio crucial en un evento, ya sea éste simple o complejo. Esto ha dado origen a interesantes "historias virtuales" como ser, un Napoleón que no fue derrotado en Waterloo, una Alemania victoriosa en la Segunda Guerra Mundial, un movimiento obrero en la Argentina sin un 17 de octubre. Se ha argumentado muchas veces que este tipo de historia es esencialmente inútil, y no pasa de un simple entretenimiento. Sin embargo, sus defensores postulan que, desde una historia virtual, puede comprenderse el presente desde la óptica de lo que éste ha conservado de sus posibilidades no desarrolladas. De este modo, sería posible conocer más en profundidad la lógica del devenir, y estudiar en qué medida los procesos históricos pueden ser determinados por sus eventos. La historia ficcional, en este caso, no puede tomar jamás la forma de una novela o de un relato de ficción, sino que debe limitarse estrictamente a un tipo de narración científica, que implique la rigurosidad propia de la Historia como ciencia, e incluso la Historiografía, en cuanto se debe documentar en detalle la "ficción". Por tanto, la Historia Virtual necesariamente desdeña o no considera significativa la historia individual, en cuanto su tipo específico de discurso no contempla personajes que, individualmente, actúen de mediadores. En este caso existe también una mediación, pero única y de diverso tipo a la que presenta la novela histórica: otra historia media entre el acontecimiento original y nuestro presente; otra causa dio un mundo igual, diferente o similar al presente de la recepción. Nuestro "otro" es colectivo. En la Historia Ficcional pura, o Historia virtual, es el acontecimiento, con su cadena diacrónica de causas y efectos y su red sincrónica de significados entre los acontecimientos mismos, la que se hace "otra", para impugnar o evaluar a la historia presente, es decir, tal como la conocemos por el relato que tenemos de ella.

Parecería entonces que necesitaríamos de un género que nos suministrara ambos aspectos de la ficción histórica: una historia otra vivida a través de personajes individuales. La misma pregunta presente en la Historia Virtual dio a luz una nueva forma de ficción: la ucronía. 
La palabra ucronía parte del mismo modelo que la palabra Utopía: Ou-Cronos, No tiempo o, más exactamente, ningún tiempo, un Tiempo Otro. Ferrater Mora lo cita con bastante detalle dentro del artículo "Utopía" en su diccionario (Ferrater Mora, 2001, p. 3623), en términos similares a la historia virtual: la descripción de un pasado que hubiera podido ser diferente del que fue en realidad (o, al menos, históricamente). ${ }^{5}$.

Este Tiempo Otro es, no obstante, la paradoja de un tiempo ya vivido, y no uno por vivir. Si bien la posibilidad de un discurso que haga verosímil el viaje en el tiempo ha sido intentada y lograda en más de una oportunidad (por ejemplo, H.G. Wells en The Time Machine, en donde el protagonista llega más bien a un mundo distópico que no es más que la realización última y monstruosa de la dialéctica hegeliana del amo y del siervo), en realidad se tratará en estos casos de una ficción, de Mundos Posibles construidos desde una alteración temporal o un viaje. El Tiempo, en la Ucronía, es esencialmente el tiempo de la Historia como ciencia, es decir, la sucesión de los eventos históricosaunque estos hayan devenido "ficcionales".

Por otro lado, ante esta Historia Alternativa la ficción ucrónica ubica a distintos personajes que actúan como "otros", como mediadores hacia ese sí mismo de nuestra identidad colectiva e individual. Estamos ante la elaboración de una Historia alternativa, un cambio en la realización de las posibilidades a partir de una modificación acaso pequeña sobre un evento histórico (o, menos frecuentemente, sobre una serie de dichos eventos). No obstante, estas modificaciones no pueden ser arbitrarias, y son experimentadas por distintos personajes. Estas perspectivas constituyen lo que diferencia a la ucronía de la historia virtual: construir una ficción con elementos históricos contrafácticos que permitan explorar no sólo el devenir histórico sino mostrar en qué medida existe dentro de la historia una dimensión individual, frecuentemente puesta de relieve a través de una estructura metaficcional: en las ucronías, es frecuente la discusión sobre la naturaleza de la ficción, y del modo en que esta ficción, estos cambios en el devenir histórico, afectan a los personajes.

Lubomír Doležel estudia específicamente las relaciones entre historia y ficción desde la teoría de los mundos posibles. Según este autor (Doležel, 1998, p. 16), "Fictional worlds of literature are a special kind of possible worlds; they are aesthetic artifacts constructed, preserved and circulating in the medium of fictional texts", y un mundo ficcional: "is a macrostructure consisting of entities (characters, objects and places) and relations between them"7. Entonces, si un mundo ficcional es una macroestructura compuesta por personajes, objetos y lugares y por sus múltiples relaciones, los mundos "ficcionales" de la ciencia histórica estarían representados también por personajes, objetos y lugares pero documentados, es decir, con un registro físico que establezca un anclaje material de

\footnotetext{
5 La ucronía es un término empleado por primera vez por el filósofo Charles Renouvier en 1857, en su libro Uchronie: l'utopie dans l'histoire: histoire de la civilisation européenne, telle qu'elle n'a pas été, telle qu'elle aurait pu être (Ucronía: la utopía en la historia: historia de la civilización europea, si aquello que no sucedió hubiera sucedido). En este libro, que tiene un carácter bastante novelesco, el autor francés propone una Europa en la que el emperador romano Constantino jamás se convirtió al cristianismo, y por tanto, dio lugar a una sociedad más laica que hubiese marcado una continuidad apreciable con el mundo clásico. En esta "historia" "no hay" Edad Media, por lo que establece una continuidad entre el pensamiento clásico y la Modernidad que, en rigor, ya no existiría como tal. De hecho, el cristianismo recién se incorporaría a la cultura occidental en su forma protestante.
}

6 "Los Mundos ficcionales en la literatura están constituidos por un conjunto especial de mundos posibles; ellos son artefactos estéticos construidos, preservados y en circulación por medio de textos ficcionales".

7 "Un mundo ficcional es una macroestructura conformada por entidades (caracteres [en el sentido de "personajes"], objetos y lugares) [nosotros incluiríamos "objetos" como memoria y tiempo] y por las relaciones entre ellos.". 
estos en el presente. Doležel habla puntualmente de "energía semántica" para definir el elemento que otorga entidad y existencia al Mundo Posible ${ }^{8}$.

Los mundos de ficción, historia y de contrafactura histórica son fundamentalmente diferentes. Mientras la ficción y la Historia constituyen mundos relativamente independientes y estructurados de manera diversa, las narrativas contrafácticas constituyen mundos que oscilan en los límites entre los mundos de la ficción y de la historia. Son, entonces, "marginales" a ambos universos, e incompletos, porque son fundamentalmente semánticos. Son construidos por un tipo específico de texto narrativo. Y poseen una estructura a la vez epistemológica y ontológica. Sus "accesos" son esencialmente ontológicos en el caso de fictional worlds, y epistemológicos en los historical worlds. Y a la vez, pueden ser físicamente localizables (historia) o fantásticos (ficcionales).

Desde una perspectiva hermenéutica, todos los sistemas semióticos han de considerarse mediaciones en el corazón de una experiencia, en el sentido fuerte y pleno de la palabra. Por tanto, podemos pensar la Historia como una Intermediación entre eventos (el pasado) y los sujetos culturales (el presente). Esta Intermediación construye la posibilidad del futuro, determina las combinaciones "plausibles" o verosímiles. Pensada de este modo, la Ucronía "crea" un evento nuevo, que se convierte en "hecho" al verificar su verosimilitud con el discurso del presente, y construye un "nuevo presente", paralelo o, más bien, alternativo, especular, semilla de una nueva cadena de posibilidades.

Encontramos en definitiva este esquema estructurante: un mundo posible que se nos ofrece, a partir de una estética del extrañamiento, como contraste del mundo "factual", el que "experimenta" el receptor. Este extrañamiento es el que habilita una toma de consciencia sobre la realidad, y nos provoca y convoca a reflexionar sobre los peligros de las decisiones que hemos tomado en el pasado, y de cómo pensamos el presente.

En resumen, podríamos esbozar las siguientes conjeturas:

1. En la Ucronía, se produce una dialéctica Hecho Histórico - Hecho Ficcional/Histórico

2. La Identidad es también (y acaso, principalmente) un constructo de lo que no se es pero se podría haber sido.

3. Entonces, la pregunta por la posibilidad histórica implica una "mediación" (en términos de Ricoeur) entre nuestro sí mismo individual-colectivo y los distintos sujetos históricos y ficcionales que podríamos representar.

4. Esta mediación es entre el sujeto histórico (del receptor, esencialmente) y su "sombra" (lo negado o lo desconocido de ese sujeto).

5. Esta mediación hacia un sí mismo individual-colectivo que propone la Ucronía muestra las contradicciones de la historia. Nos introduce en una ambigüedad no-determinista (implica una apertura hacia la teoría del Caos).

6. La Ucronía puede pensarse como una forma ficcional del revisionismo histórico no centrada en los datos concretos (historiografía) sino en la estructura narrativa. Le quita a la historia su "horizonte ontológico" y la convierte en una suerte de "relato flotante" sobre una infinitud de

\footnotetext{
${ }^{8}$ Walter Benjamin vio este punto con enorme claridad, al articular el concepto de lo mesiánico (propio de las religiones monoteístas) con el materialismo histórico: no se trata de un punto que puede alcanzarse; se trata, más bien, de un horizonte siempre lejano cuya vista a la distancia, sin embargo, otorga "energía" al sistema.
} 
relatos "sumergidos" y posibles.

Pero es preciso remarcar un elemento nuevo, que se vuelve particularmente visible en la ucronía: estamos ante un modo complementario de comprender la historia; no ya sólo como una relación causa-efecto, que determina los acontecimientos y los hechos, sino fundamentalmente como una relación de sincronía entre acontecimientos. La famosa pregunta "qué hubiera pasado si”, propia de la ucronía y de la historia virtual, puede no modificar las causas profundas de un acontecimiento complejo (por ejemplo, el surgimiento del nazismo), sino la sincronía dentro de la cual este acontecimiento se carga de sentido. En realidad, deberíamos hablar de "constelación de acontecimientos" para definir un hecho histórico. Esta constelación se estructura sincrónicamente, y deviene como una unidad en constante transformación (puede perder o incorporar elementos).

La estructuración de la trama narrativa, tal como es pensada y elaborada tradicionalmente, establece una vinculación del tipo causa-efecto: construimos una trama que "conecta" determinados efectos con causas específicas. Es decir, en sentido inverso a cómo han ocurrido diacrónicamente los acontecimientos; conectamos los efectos, una vez que ellos han sido considerados "significativos" por nuestro presente, con sus "causas", cuando también han sido considerados capaces de "significar" el acontecimiento.

Encontramos aquí, sin embargo, otro aspecto fundamental: la sincronía que existe entre los acontecimientos. Así como la relación causa-efecto es "vertical" (toda causa es anterior a su efecto) y genera sentido a partir de esta específica linealidad, pero construida inversamente, las relaciones de sincronía son "transversales", mucho más complejas de medir, y en general cargan de significado al acontecimiento central, frecuentemente ocultándose en él. La ucronía opera, en realidad, más que a partir de una modificación en las causas, en una modificación en la estructura de esta sincronía? La aparición o supresión de un hecho, lograda ficcionalmente, implica una reconfiguración de toda la estructura, tanto vertical como transversalmente. Esto hace a una doble operación: sobre la diacronía de los hechos (causas específicas previas a efectos puntuales) y a la vez sobre su sincronía (eventos diversos que convergen resignificándose y reconfigurándose).

Observemos que la ucronía propone que el devenir histórico no depende tanto del acontecimiento en sí sino de la sintaxis que dichos acontecimientos conforman dentro del relato. En términos menos complejos, podemos pensar esta estructura como una "gramática" de la ficción histórica. A nuestro juicio, esta gramática implicaría al menos tres reglas básicas:

1. Los acontecimientos deben ser verosímiles a partir de su derivación con respecto a un relato al que inevitablemente se referencian (la Historia, la instancia de enunciación). Este relato conforma el espacio de experiencia.

\footnotetext{
9 Para tomar un ejemplo clásico del género, pensemos en la novela The Iron Dream, de Norman Spinrad, en donde se plantea un mundo posible muy singular: Hitler no se dedicó a la política pero sí a la literatura, lo que puede verse o pensarse como "causa" de un evento mayor que es "la no ocurrencia de la Segunda Guerra Mundial". En realidad este evento sucedió "en sincronía" con una multiplicidad de otros eventos y de otros actantes históricos (el papel de la URSS ante ese "vacío", o el rol que podría haber tomado la derecha francesa). Por ejemplo, Spinrad propone en esta novela, más cercana al género de la Ciencia-Ficción, que el genocidio fue llevado a cabo por la URSS: la sincronía "reconfiguró" todo el sistema complejo de la historia europea en "otra historia" que, sin embargo, deviene esencial y trágicamente idéntica. Parafraseando a Borges en su cuento "Emma Zunz", "sólo han cambiado el tiempo, el lugar, y algunos nombres propios".
} 
2. Estos acontecimientos son reorganizados de modo que entre ellos exista a su vez un "relato verosimilizador", un relato que garantice la consistencia de la ficción. Este relato está "ausente", o no está explícitamente en el texto, pero debe estar presente de tal modo que pueda ser inferido a partir de la exposición de estos mismos acontecimientos. En general, este relato es la "Historia" de ese mundo posible.

3. La sintaxis de los eventos configura un "futuro posible" doblemente ficcional a partir de dos "Historias" diferentes, la virtual (la que existe dentro de la ficción) y la configural (la que comparten como espacio común de experiencias y como horizonte de expectativas el autor y los receptores). Este futuro posible en el texto determina un "horizonte de interrogantes" en el receptor que debería exceder su "horizonte de expectativas". En este caso, se tiende a transmutar una situación histórica en otra que, sin embargo, deviene esencialmente similar, casi idéntica. Sólo han cambiado sus aspectos contingentes.

En definitiva, estamos ante una polifonía de horizontes de posibilidades en donde el receptor, autoextrañándose a través de distintos personajes, juzga su presente histórico. En los capítulos siguientes, aplicaremos este modelo de análisis a la ya citada novela de Philip Roth, y su singular ucronía.

\section{Tema y estructura de la novela: La construcción del "miedo perpetuo"}

Philip Roth se preocupa, en su novela, por remarcar el carácter histórico de la situación, su lugar, su tiempo y sus actantes. Incluso la alteración del acontecimiento histórico es muy puntual, y no produce un cosmos completamente nuevo con el cual trazar paralelismos. Podríamos afirmar, y no como defecto sino, precisamente como mérito creativo, que la novela es poco "imaginativa": más que una alteración definitiva de los hechos, lo que se produce es una curiosa "postergación" de un desenlace común con el mundo "fáctico", el de la historia documentada que conocemos (la tercera presidencia de Roosevelt y la victoria aliada en la Segunda Guerra Mundial). Es como si el autor hubiese decidido intercalar una pesadilla dentro de una historia con final feliz, una pesadilla de la que finalmente se despierta. El tema, el verdadero sentido de esta inserción, de esta ucronía, está en lo que sucede después del despertar: esta pesadilla no nos dejará en paz, pero sí una suerte de "residuo" en nosotros que el tiempo difícilmente disipe. Un residuo que contamina ambos mundos de realidad e irrealidad a la vez.

Hablar de esta pesadilla y de su residuo parece ser el objetivo de Philip Roth. El autor adopta un punto de vista, una focalización para construir a su narrador, que define desde un comienzo el "mundo" de la novela. Ya el primer párrafo, que corresponde al capítulo inicial June 1940-October 1940 / Vote for Lindbergh or Vote for War, constituye una inquietante puesta en abismo:

Fear presides over these memories, a perpetual fear. Of course no childhood is without its terrors, yet I wonder if I would have been a less frightened boy if Lindbergh hadn't been president or if I hadn't been the offspring of Jews. (Roth, 2005a. p. 1) $)^{10}$

\footnotetext{
10 El temor gobierna estas memorias, un temor perpetuo. Por supuesto, no hay infancia sin terrores, pero me pregunto si no habría sido yo un niño menos asustado de no haber tenido a Lindbergh por presidente o de no haber sido vástago de judíos (Roth, $2005 b$, p. 11)
} 
Roth escribe "Miedo" (Fear) como "sujeto" de esta oración que, además de gravitar sobre todos y sobre todo, es el particular, específico miedo de un niño. Un miedo perpetuo, sin posible final. La pesadilla asoma de la estructura condicional - hipotética que sigue a este miedo: no childhood is without its terrors (no hay infancia sin terrores), pero I wonder if I would have been a less frightened boy (me pregunto si yo habría sido un niño con menos miedo) if Lindbergh hadn't been president (si Lindbergh no hubiera sido presidente) o if I hadn't been the offspring of Jews (o si yo no hubiese sido un vástago de Judíos). La primera hipótesis es el resultado de la historia ficcional que va a desarrollarse en la novela. La segunda, en cambio, continúa el mundo "real": tanto en el "mundo posible" como en el mundo de los hechos, el niño es vástago de judíos. Acaso Roth adulto, el que se construye a sí mismo como niño, quiere recuperar su fe en la historia, y en particular, en la historia norteamericana, y la pone a prueba de una manera terrible.

¿Qué habría pasado si Charles Lindbergh, héroe nacional norteamericano, el primer aviador en unir en vuelo directo Nueva York y París, el mártir por haber perdido a su hijo en un secuestro devenido en asesinato, hubiera sido presidente de EE.UU.? ¿Podría haber desarrollado un gobierno totalitario y fascista? The plot against America es la pregunta, que el autor de alguna manera responde implícitamente: si la pregunta puede ser formulada de manera verosímil, entonces su respuesta ya aparece encriptada en su interior. Que los hechos que nos separan de esta historia alternativa sean tan puntuales, constituye un reflejo de lo presente, de un miedo que, desde esa otra historia, planea sobre nosotros. Es preciso entonces tener fe en la historia, como el propio Roth parece tener, y no perderse en el nihilismo. Una fe ambigua, de todos modos, porque sobre ella gravita el miedo.

Ya el índice nos da la pauta organizativa de la novela, estrictamente jerárquica en su desarrollo. Sus nueve capítulos y un apéndice se despliegan del siguiente modo:

1. June 1940 - October 1940. Vote for Lindbergh or Vote for War (Junio 1940 - Octubre 1940. Votad por Lindbergh o Votad por la Guerra)

2. November 1940 - June 1941. Loudmouth Jew (Noviembre 1940 -Junio 1941. Judío Bocazas)

3. June 1941 - December 1941. Following Christians (Junio de 1941 - Diciembre de 1941. Seguimiento de Cristianos)

4. January 1942 - February 1942. The Stump (Enero 1942 - Febrero 1942. El Muñón)

5. March 1942 - June 1942. Never Before (Marzo 1942 - Junio 1942. Nunca hasta entonces)

6. May 1942 - June 1942. Their Country (Mayo 1942 - Junio 1942. Su país)

7. June 1942 - October 1942. The Winchell Riots (Junio 1942 - Octubre 1942. Los disturbios causados por Winchell)

8. October 1942. Bad Days (Octubre 1942. Días malos)

9. October 1942. Perpetual Fear (Octubre 1942. Miedo perpetuo)

10. Postscript (Apéndice)

- Note to the Reader (Nota para el lector)

- A True Chronology of the Major Figures (Cronología real de los personajes principales) 
- Other Historical Figures in the Work (Otros personajes históricos que aparecen en la obra)

- Some Documentation (Algunos documentos)

El período que articula la diégesis (narración) de la novela (es decir, sin incluir el Apéndice, ya que éste es "estrictamente" histórico -ya veremos qué implica este entrecomillado) abarca un lapso relativamente breve: desde junio de 1940 hasta octubre de 1942. Es decir, poco más de dos años (28 meses para ser exactos). Estos nueve períodos en que se estructura ese lapso tienen un título que los define y articula:

1. Votad por Lindbergh o votad por la guerra abarca todo el período pre-electoral, en donde Lindbergh es nominado como candidato del partido Republicano. En la historia documental, en efecto se dio en esta misma campaña electoral la asociación de Roosevelt con una hipotética participación de EE.UU. en la guerra. Durante toda esa campaña, y en su gobierno hasta el ataque japonés a Pearl Harbour en diciembre de 1941 (es decir, más de un año desde esas elecciones) Roosevelt debió cuidarse mucho de ser muy explícito con la ayuda que remitía a los enemigos del Eje (Gran Bretaña en particular, y en mucha menor medida la URSS). Sólo el ataque japonés legitimó una actitud belicista por parte de EE.UU.11

En la ficción, la aparición de Lindbergh desbarata el proyecto de Roosevelt. La lógica de la campaña del aviador consistió solamente en diferenciarse en este aspecto de su rival. Esto, sumado a su prestigio y a la actitud de algunos aliados de Lindbergh, por ejemplo el rabino Bengelsdorf, asegurará su victoria.

2. Judío bocazas muestra la paulatina estigmatización que, luego de la ascensión de Lindbergh, se manifiesta en la sociedad norteamericana hacia los judíos. Lo interesante del modo en que esto se producirá es que no constituye nunca una explícita política de gobierno. La administración republicana logra infiltrar paulatinamente en la sociedad la idea de conformar a EE.UU. como "un solo pueblo" (Just Folks, tema sobre el que nos detendremos especialmente). Todo grupo que evidencie una identidad propia fuerte será visto como un enemigo de la identidad norteamericana. "Naturalmente", esta estigmatización recaerá sobre los judíos norteamericanos.

3. Seguimiento de Cristianos, el pequeño Philip Roth, junto con su amigo Earl Anxman, que cumple cierta función de "guía" o "iniciador" sobre Philip (lo ha introducido en los secretos del sexo femenino mostrándole la ropa interior de su madre), siguen por la ciudad a distintos personajes que reconocen como cristianos. En realidad, el juego se propone como una suerte de espejo o parodia de otro seguimiento, mucho más siniestro, que se da simultáneamente: el que distintos agentes del FBI hacen sobre los judíos, y sobre la familia de Philip en particular. La lógica de este seguimiento es amplia, ya que se vigila a su familia desde dos aspectos: por su tía Evelyn, vinculada al rabino Bengelsdorf (director de la muy significativamente

\footnotetext{
${ }^{11}$ Una de las cuestiones más criticadas en la actitud de Roosevelt fue su intención de presentarse en las elecciones de 1940. Esta actitud fue juzgada por muchos de sus adversarios políticos como una suerte de "golpe de estado", ya que es una tradición en la política norteamericana (inaugurada por George Washington) que ningún presidente busque un tercer mandato. Roosevelt es el único caso en toda la historia norteamericana de un presidente elegido en más de dos oportunidades; de hecho, lo fue en cuatro, claro que este último período (que no concluyó, debido a su muerte en 1945) fue en buena medida producto del mismo contexto de la guerra.
} 
denominada O.A.A.: Oficina de Absorción Americana), y especialmente por su primo Alvin, que se habia enrolado (en el cap. 1) en el ejército canadiense para combatir al nazismo, y que ha regresado mutilado.

4. El Muñón, la historia del regreso de su primo Alvin, que vive con un fuerte desencanto su frustrada experiencia de lucha. Ha regresado mutilado (ha perdido una pierna) y el eje de este capítulo es precisamente el muñón infectado de Alvin, y las vicisitudes que tienen tanto él como Philip, que lo ayuda, para curarse y poder emplear su pierna ortopédica. Este muñón, símbolo acaso de un idealismo mutilado desde un comienzo, pesa sobre la familia y se hace metáfora de un compromiso que la sociedad no logra asumir para su propia defensa.

5. Nunca hasta entonces, presenta una situación inimaginable en otro contexto: la recepción que se le hace a un jerarca nazi en la Casa Blanca. Von Ribbentrop, Ministro de Relaciones Internacionales del III Reich, es recibido por Lindbergh y su esposa, y esta actitud, que después el narrador explicará como una "inspección" que los aliados "alemanes" harán de "la política interior" en lo que hace a los judíos y otros grupos minoritarios, marcará el principio de una reacción por parte de la oposición demócrata.

6. Su País, es la consumación de la política del Just Folks por parte de la Oficina de Absorción Americana. El propio padre de Philip es "invitado" por su empresa (irónicamente, la compañía de seguros de vida Metropolitan Life) a trasladarse a Kentucky (en donde el hermano de Philip ya había estado como parte de un programa de integración). Su País, es el país del Just Folks, y no pertenecer a él será autoexcluirse. Esto será, en efecto, lo que ocurrirá, y el padre de Philip deja su trabajo para no ser transferido y no dejar su hogar, aun cuando eso lo obligará a buscar un trabajo más duro y peor remunerado.

7. Los disturbios causados por Winchell, el periodista (no desprovisto de cierto amarillismo, posiblemente necesario ante el rol que cumple en la ficción) Walter Winchell es un personaje histórico, tal como Lindbergh, Roosevelt o Bengelsdorf, que a lo largo de toda la ficción adopta la voz de la denuncia constante del antisemitismo del gobierno. Ante la situación que se plantea a esta altura de los acontecimientos (estamos ya en junio de 1942), Winchell se postulará como candidato presidencial independiente, y sus arengas públicas generarán una cadena de disturbios antisemitas que concluirán con su asesinato. Este es precisamente uno de los más significativos puntos de inflexión de la novela. Winchell, que en cierto modo tiene el fin de un mártir, hace evidente más allá de toda duda la verdadera ideología de Lindbergh, y el sentido de su política.

8. Días malos, son los días de Octubre de 1942, que significativamente, coinciden con un mes trascendental en la historia documentada de la Segunda Guerra Mundial. En efecto, este mes marcó un profundo cambio en el desarrollo de los acontecimientos bélicos, con el inicio de la batalla de Stalingrado en Rusia, El Alamein en el Norte de África, junto con la intervención norteamericana en las colonias francesas hasta entonces neutrales, y el comienzo de los largos combates en las islas Salomón, en el Pacífico. Roth autor, probablemente, ha hecho coincidir el comienzo del fin del gobierno de Lindbergh en la ficción histórica con el comienzo 
del fin del Eje en la historia documental. El contexto en la ficción es una pelea entre Alvin y el padre de Philip, que deja malheridos a ambos, y en el que interviene, como una suerte de Deus ex machina propio de la comedia, un vecino italiano (calabrés para ser más preciso), el señor Cuccuzza, que los separa y evita que se maten entre sí. Esta situación con final de comedia es una puesta en abismo del Deus ex machina de la historia ficcional. Es en este punto en donde el narrador, que hasta ahora fue exclusivamente en primera persona, adopta imprevistamente una focalización diferente, y narra los sucesos de la historia ficcional a partir de notas de periódicos y otros documentos. Luego de los funerales de Winchell, Lindbergh desaparece con su avión sin dejar rastros, y este hecho alimenta conjeturas y rumores de todo tipo, que abarcan desde un plan británico para secuestrarlo hasta un complot en la Alemania nazi, en donde el hijo de Lindbergh está recluido (aquel hijo que supuestamente había sido asesinado diez años antes), y mediante el cual el aviador y presidente fue chantajeado constantemente y "obligado" a actuar de manera pro-nazi. Esto precipita primero una profundización de la persecución política (Roosevelt, el alcalde de Nueva York, Fiorello La Guardia; Bengelsdorf y la propia esposa de Lindbergh son arrestados bajo sospecha de conspiración; incluso, EE.UU. llega a un virtual estado de guerra con Canadá, es decir, con el Reino Unido). Luego, a partir de un llamado que la Primera Dama hace al pueblo norteamericano, en donde denuncia el complot, la opinión pública logra revertir la situación.

9. Miedo perpetuo, la narración, con el narrador ya habitual, este Roth autobiográfico-ficcional, retrocede unos días, ubicándose precisamente antes de la denuncia de la conspiración. El eje es precisamente el asesinato de la madre de Seldon, que había sido trasladada por la O.A.A. a Kentucky (como debería haber ocurrido con el padre de Philip). Este asesinato es la marca del miedo, de ese miedo perpetuo, que se introduce dentro de la comunidad. Es la marca de lo terroríficamente posible.

El miedo, omnipresente y en un angustioso crescendo que no cede incluso después del triunfo de los demócratas, se impone como una auténtica "fuerza actancial" que reconfigura para siempre la conducta de todos los personajes y su horizonte de expectativas. De algún modo, la memoria atesorada en la familia y la comunidad, constituirá el refugio y una forma de resistencia para sobrevivir dentro de esta "perpetuidad ominosa".

\section{Memoria y Constelación Familiar}

Como ya explicamos, el narrador, único durante la mayor parte de la novela, es una ficcionalización del propio autor, a través de la particular focalización de su propia infancia, y de un específico momento de ella. En términos narratológicos, es un narrador homodiegético, en cuanto narra parte de su experiencia dentro de una historia de la que no es su protagonista principal ${ }^{12}$. En principio, parecería que Roth personaje-narrador se instala a sí mismo como "mediador". Pero la estructura

\footnotetext{
12 Narrador homodiegético: es la entidad que vehicula informaciones adquiridas por su propia experiencia diegética; esto quiere decir que, habiendo vivido la historia como personaje, el narrador ha extraído de ahí las informaciones de que carece para construir su relato [...] difiere de [el narrador autodiegético] por haber participado en la historia no como protagonista, sino como figura cuya importancia puede ir desde la posición de simple testigo imparcial hasta la de personaje secundario estrechamente solidario con el central. (Reis y Lopes, 1995, p. 161)
} 
es más compleja que esto, ya que si bien al narrar todo lo concerniente a la historia ficcional, es un personaje secundario, no lo es cuando describe su propia experiencia iniciática de niño. En este punto, deberíamos pensarlo entonces como una curiosa oscilación entre narrador homodiegético y autodiegético. Esta distinción no es meramente clasificadora, sino que responde a la misma lógica de la narración.

Debemos recordar que tanto el personaje como el mismo narrador son ficcionales, y en particular, autoficcionales, como si el autor los utilizara de máscara y confundiéramos esa máscara con la persona. La focalización desde un niño que forma parte de una constelación familiar nos debe advertir de una interesante maniobra compositiva: en realidad, el niño aporta el foco, pero la mediación narrativa se produce por esta misma constelación familiar, que conforma el universo moral y conceptual del niño, del que el foco es sólo un punto de referencia, fundamental pero no excluyente.

El entorno familiar que constituye el campo de observación tiene la composición típica de una familia pequeñoburguesa. Entre paréntesis, incluimos el rol más importante que representan dentro de dicha constelación:

- El padre (la ley)

- La madre (la conexión con la vida y lo sagrado)

- El hermano, Sandy (el adaptable)

- El primo Alvin (el inadaptable, el contestatario)

- La tía Evelyn (la colaboracionista)

La dialogía que el narrador construye entre esta constelación familiar y el desarrollo de la política y la historia puede pensarse como una suerte de autobiografía ficcional, en una relación dialéctica permanente con la Historia Ficcional. Por tanto, la condición del narrador aparece desdoblada, ya que es homodiegético en cuanto a la Historia Ficcional y a algunos hechos de su entorno, y es autodiegético cuando narra sus propias experiencias, en particular las iniciáticas en un niño. Esta dialéctica se articula para mostrarnos cómo la constelación se ve afectada en sus relaciones, tanto íntimas como externas, por la Historia Ficcional.

Entendemos por Constelación un sistema dinámico-complejo de relaciones, humanas en este caso, que se construye conformando una identidad dinámica con dos "fuerzas" o "puntos de referencia": una "gravitación" interna, que tiende a la unidad de la constelación; y una "externa" que hace a la forma en que esta constelación "dialoga" con el mundo.

Esta unidad tiene su centro en la figura de la madre del pequeño Philip, que actúa a su vez de conexión con el pasado religioso de su pueblo. Ella es la que enraíza a la constelación dentro de su comunidad, quien convierte a la constelación en un sujeto cultural, que el narrador hace explícita en varios momentos de la novela, y en particular en el párrafo siguiente:

each Friday at sundown, when my mother ritually (and touchingly, with the devotional delicacy she'd absorbed as a child from watching her own mother) lit the Sabbath 
candles, she invoked the Almighty by his Hebrew title but otherwise no one ever made mention of "Adonoy". These were Jews who needed no large terms of reference, no profession of faith or doctrinal creed, in order to be Jews, and they certainly needed no other language -they had one, their native tongue, whose vernacular expressiveness they wielded effortlessly [...] What they were was what they couldn't get rid of-what they couldn't even begin to want to get rid of. Their being Jews issued from themselves, as did their being American. (Roth, 2005a, p. 220) ${ }^{13}$

Esta ceremonia, con su vínculo con lo sagrado, define (según Roth) una forma particular de pensarse miembro de una comunidad: no es la observancia rigurosa de un dogma, ni una prescripción en cuanto a vestimenta, alimentación o costumbres. Se trata, sencillamente, de un vínculo más allá de la historia, que da sentido a la historia de esa comunidad. Es este rito lo que conforma el proceso de reafirmación de una cultura ${ }^{14}$. Es precisamente esto lo que está en peligro, aun más que los propios individuos. Tal como Roth lo concibe, el proyecto de Lindbergh implica fragmentar, "historizar" a los judíos norteamericanos dentro de un proceso, del que resultarán reinsertados con un nuevo horizonte "ahistórico": serán norteamericanos, más allá de sus orígenes. Esta "americanidad" es el núcleo del cambio cultural e identitario proyectado. Es así que Roth desarrolla un modelo de aplicación de un auténtico etnocidio en una sociedad "democrática" (es decir, pretendidamente plural).

Esta situación funciona como un proceso "etnocida" en escala limitada en cuanto a profundidad, pero abarca el país entero en cuanto a extensión, y podríamos llamarlo (evocando a Nietzsche) la construcción y la destrucción del templo (Nancy, 2008, p. 19): "A fin de que un santuario pueda ser erigido, un santuario debe ser reducido a fragmentos". $\mathrm{O}$, dicho de otra manera, para que una identidad nazca, otra debe ser destruida. Oponerse a perder la propia identidad es traición a la identidad que debe nacer (proceso que tiende a oponer pasado-futuro, como si ambos no estuvieran íntimamente compenetrados y fueran interdependientes). El sentido o telos de la historia es, para Roth, el de una comunidad que resiste el avance de un estado que la niega.

De este modo, la autobiografía ficcional oscila entre lo "histórico" y lo "ahistórico" de su vida; esta oscilación es amplificada en Roth por la Historia Ficcional, que actúa de marco o cosmos, pero no desde la oscilación memoria-olvido sino historia-ficción. Por esto, encontraríamos dos planos de desarrollo de la diégesis, uno individual, marcado por la dialéctica memoria-olvido, propio de la autobiografía como género, y otro colectivo, marcado por la dialéctica historia-ficción, propio de la historia ficcional. La construcción de este personaje múltiple para la mediación, esta constelación familiar, permite reflejar las propias contradicciones en el interior de este "sujeto" (las contradicciones del propio sujeto colectivo Jews), que existe en cuanto autobiografía inmersa en la historia.

\footnotetext{
13 "cada viernes al ponerse el sol mi madre, de una manera ritual (y conmovedora, con la devota delicadeza que absorbiera de niña al contemplar a su propia madre), encendía las velas del Sabbath e invocaba al Todopoderoso por su título hebreo, pero por lo demás nadie mencionaba nunca a "Adonai". Eran aquellos unos judíos que no necesitan grandes términos de referencia, ninguna profesión de fe ni ningún credo doctrinal para ser judíos, y ciertamente, no precisaban de otro lenguaje, pues ya tenían uno, su lengua materna, cuya expresividad vernacular manejaban sin esfuerzo [...] Eran aquello de lo que no podían liberarse, de lo que de ninguna manera podrían pensar ni siquiera en liberarse. El hecho de ser judíos provenía de ser ellos mismos, como sucedía con el hecho de ser americanos". (Roth, 2005b, p. 244)
}

\footnotetext{
14 Recordemos que la etimología sánscrita de "rito" se refiere a aquello que está conforme con el orden; de ahí su presencia en términos como ritmo o aritmética.
} 
Por la misma lógica con la que es construida, la ucronía opera como un sueño terrible que invade al grupo en la ficción, y a nosotros en el mundo factual. La "pesadilla" modificará definitivamente las relaciones en el interior de la constelación, y su conexión con el mundo, y a través de su mediación tendremos la experiencia de este terror, sin estar concretamente inmersos en él. Para Jay (Jay, 1993 , p. 178) esta mediación es, desde el punto de vista de la autobiografía, una "cura" en el sentido freudiano del término. Esto implica diluir deliberadamente los límites entre lo ficticio y lo factual (Jay, 1993, p. 189), y construir un referente nuevo, el yo (Roth autor, la constelación, el receptor) y amplificar los límites de su sujeto.

El "trabajo" de construir este relato, y su recepción constituyen formas de reintegrar este aspecto oscuro, ya en la ficción como en el mundo factual, al mundo consciente, y elaborar el trauma (la pesadilla), presente y ausente a la vez, según el mundo en el que nos ubiquemos, pero siempre mostrándose. No obstante, el contexto de la enunciación (el tiempo en que Roth escribe esta novela, los años 2004 y 2005) posee una particular significación para la forma en que es producida esta mediación: no es la cuestión judía concretamente lo que está en juego en la cultura y la sociedad norteamericanas, sino la misma posibilidad de reivindicar una individualidad.

De este modo, memoria y acontecimiento conforman también una dialéctica, implícita tanto en la autobiografía como en la historia. Toda la novela de Roth se basa en este continuo diálogo en busca de síntesis entre el individuo con la historia, de la propia comunidad con el individuo, y de la comunidad con la historia, con todas las variantes intermedias posibles. Por eso, en la constelación los roles particulares determinan qué conflictos o identidades introducen cada uno. Así como el actante "Roth niño" refleja sobre todo el "miedo", la figura del padre es la encargada de reinsertar la historia (ficcional en este caso, pero "factual" para él) dentro de la constelación. El "Roth narrador" (un ficticio Roth adulto, construcción también él de un Roth autor) es el que articula todos estos aspectos, estos "caminos narrativos", otorgándole una doble perspectiva histórica a estos acontecimientos habitados por la memoria. En la ubicua encrucijada de estos caminos se encuentra la también ubicua verdad histórica.

\section{Estigmatizaciones, o fragmentar para unir:}

La idea que marca la política de Lindbergh es la unidad étnica norteamericana. Just Folks implica este principio, que si bien no es explícitamente racista en el sentido biológico del término, contiene un fuerte rechazo a todo rasgo cultural individual, no amalgamado en lo norteamericano, concepto vago en sí mismo, ya que como toda identidad, debe también construirse. Esta construcción implica, necesaria y paradójicamente, la necesidad de destruir. Hay que fragmentar la sociedad (en rigor, las sociedades, las colectividades específicas) para poder reunir los pedazos de ese cuerpo social de otra manera. Pero esta fragmentación requiere de un particular proceso de ingeniería, uno de cuyos ejes es facilitar la disgregación de estos componentes entre el inmenso territorio de EE.UU. Para lograrlo, este proceso debe pasar, primero, por una etapa de estigmatización: es preciso no sólo reducir la resistencia de los grupos a desunirse, sino sobre todo minar su autoestima. Sólo a partir de un rechazo, aunque leve, de la propia cultura particular es posible continuar con este 
proceso. Lindbergh, en la novela, lo lleva adelante de manera singular, digamos, de un modo muy norteamericano: no a partir de una explícita política gubernamental de estigmatización, sino democratizándola, haciendo que el propio pueblo actúe. Este proceso de estigmatización implica mostrar el componente "degenerativo" de la sociedad, una suerte de rechazo a los elementos "no puros" en ella. Y, en efecto, cobra una fuerza singular cuando es ejercida no explícitamente desde el ámbito del poder político, sino por ciudadanos comunes, y amplificado por el valor simbólico del lugar en donde se produce: El Lincoln Memorial, precisamente el lugar que preserva la memoria del presidente más importante en la historia norteamericana en lo que se refiere al ejercicio de la libertad y los derechos civiles. El eje de la estigmatización se produce a raíz de un comentario de una mujer de cierta edad, que compara a Lindbergh con Lincoln:

November 1940 - June 1941

Loudmouth Jew

Compare Lincoln to Lindbergh Boy oh boy, my father moaned.

In fact the elderly lady was not alone but with a group of tourist, among whom was a man of about my father's age who might have been her son.

"Something bothering you?, he asked my father, assertively stepping in our direction.

Not me, my father told him.

Something bothering you about what the lady just said?

No, sir. Free country.

The stranger took a long, gaping look at my father, then my mother, then Sandy, then me. And what did he see? [...] And the conclusion the stranger drew from his observations he demonstrated with a mocking movement of the head. Then, hissing noisily so as to mislead no one about his assessment of us, he returned to the elderly lady and their sightseeing party, walking slowly off with a rolling gait that seemed, along with the silhouette of his broad back, intended to register a warning. It was from there that we heard him refer to my father as "a loudmouth Jew", followed a moment later by the elderly lady declaring, "l'd give anything to slap his face" (Roth, 2005a, pp. 64-65) ${ }^{15}$

El entorno resignifica la situación de manera grotesca y siniestra a la vez. Comparar a Lincoln con

\footnotetext{
15 “¿Está comparando a Lincoln con Lindbergh? - protestó mi padre-. Lo que hay que oír.”

"En realidad, la anciana señora no estaba sola, sino con un grupo de turistas, entre ellos un hombre de la edad de mi padre que podría haber sido su hijo".

"-¿Tiene algún problema con lo que esta señora acaba de decir?"

"-No Señor. Estamos en un país libre".

"El desconocido dirigió a mi padre una larga mirada de extrañeza, y después, uno a uno, nos miró a mi madre, a Sandy y a mí. ¿Y qué es lo que veía? [...] Y el desconocido reflejó la conclusión que había extraído de sus observaciones cabeceando con expresión burlona. Después, siseando ruidosamente para que nadie malinterpretara el juicio que le merecíamos, volvió al lado de la anciana y el grupo de turistas, caminando lentamente y con un balanceo que, unido a la anchura de los hombros, parecía expresar una advertencia. Desde allí le oímos referirse a mi padre como 'un judío bocazas', palabras a las que poco después siguieron las de la anciana señora: 'Cómo me gustaría abofetearlo'” (Roth, 2005b, pp. 80-81)
} 
Lindbergh, para el personaje del padre de Roth, constituye un auténtico insulto, ya que el segundo no posee ni siquiera un discurso humanista. Desde el punto de vista literario, la forma en que Roth autor presenta la situación es magistral, ya que realiza un crescendo que comienza con una mera comparación y concluye con la explicitación de un deseo (ya, diríamos, una promesa) de agresión moral y física. Esta progresión comienza de una manera casi humorística, a partir del comentario de una anciana, turista también, quien hace la primera comparación. El absurdo (o, en todo caso, el abismo ético que separa a Lincoln de Lindbergh) adquiere particular fuerza cuando interviene un hombre (de aproximadamente la misma edad que el padre de Roth), quien objeta el malhumor del padre. Éste, a su vez, le observa que "están en un país libre" (Free country). Nueva ironía, porque el contexto es evidentemente represivo, si bien nadie (ni la anciana, ni el hombre adulto, ni la familia Roth) ha quebrantado la ley. La situación se vuelve particularmente tensa cuando el hombre que los ha interpelado los observa con profundo detenimiento, y en estricto orden (primero al padre, luego, a la madre, a Sandy y por último a Philip). ¿Qué es lo que veía?, se pregunta Philip. El narrador no lo dice directamente porque no es necesario: la búsqueda de rasgos raciales y sociales específicos que permitirán encasillar al padre de Roth como "judío" y, por añadidura, "bocazas" (loudmouth jew). El calificativo principal es "judío", quien además "habla más de la cuenta" (es decir, "habla de lo que no sabe", o bien, "dice mentiras", o "es un estúpido"). El gesto y el comentario final de la anciana sellan el proceso: "me gustaría abofetearlo", lo que se hace con los elementos "degenerados" de la sociedad.

El programa Just Folks, que el traductor de la novela al español traduce como "solo pueblo"), merece que nos detengamos en su nombre: Folk posee en inglés un sentido similar al Heimat del alemán o al Paese italiano, pero que en español carece de un término específico, ya que los diversos sentidos de "pueblo" dependen en gran medida del contexto en que la palabra es utilizada. Se refiere básicamente a la patria "chica", al pueblo en un sentido casi de intimidad, de gran familiaridad. Su sentido "étnico" refuerza lo dramático de su objetivo: no un "solo pueblo" en el sentido de formar una única nación, sino una "sola etnia", "justamente una sola etnia". Por tanto, el objetivo es mucho más ambicioso que construir un único pueblo. Se trata, por el contrario, de uniformar la cultura a partir de un modelo específico: la sociedad norteamericana del medio este, Kentucky en particular. Esencial en este proceso es la figura del rabino Bengelsdorf, quien, para asombro de muchos judíos (entre ellos, el propio padre de Philip) se incorpora al equipo de campaña de Lindbergh. En una sociedad como la norteamericana, de larga tradición democrática y con pocos, aunque relevantes, antecedentes antisemitas, es preciso "preparar" este clima de estigmatización y fragmentación, y para esto es necesario legitimar los discursos del candidato y luego presidente republicano. Esta legitimación implica mostrar efectivamente que no es antisemita. El momento crítico en que esto se logra lo constituye el discurso que el rabino Bengelsdorf hace antes de las elecciones presidenciales, habilitando de este modo una línea de pensamiento en la sociedad que no asociará a Lindbergh con el antisemitismo. Este discurso es muy extenso, estratégicamente interrumpido en algunas ocasiones por comentarios del padre de Philip y de su primo Alvin, comentarios que nos permiten evaluar la "recepción" que en la comunidad judía podría haber tenido un discurso semejante. Reproducimos un pequeño fragmento, de modo de poder evaluar las contradicciones que implica:

I oppose their treatment [los nazis a los judíos] with every ounce of my strength, and 
so too does Colonel Lindbergh oppose their treatment. But, how will this cruel fate that has befallen them in their own land be alleviated by our great country going to war with their tormentors? [...] Yes, I am a Jew, and as a Jew I feel their suffering with a familial sharpness. But I am an American citizen, my friends -again the applause[...] and so I ask you, how could my pain be lessened if America were now to enter the war and, along with sons of our Protestant families and the sons of our Catholic families, the sons of our Jewish families were to fight and die by the tens of thousands on a blood-soaked European battleground? [...]

- Koshering Lindbergh -Alvin said-. Koshering Lindbergh for the goyim. [...]Don't you see, Uncle Herman, what they got the great Bengelsdorf to do? He just guaranteed Roosevelt's defeat! (Roth, 2005a, pp. 39-40) ${ }^{16}$

Volver "kosher" a Lindbergh es, replicando la metáfora alimenticia, hacerlo digerible para los gentiles, incorporarlo dentro de lo aceptable políticamente. Esto provoca, desde el punto de vista de la recepción, una curiosa lectura "desdoblada". En efecto, el receptor teórico del discurso no son los judíos, sino el norteamericano medio, no antisemita y eventual votante de Roosevelt. La inclusión de la voz favorable de un rabino junto a una figura sospechada de ser pro-nazi, legitimaría una lectura no-nazi de este último.

Este es el comienzo embrionario de Just Folks: el rabino remarca con riguroso énfasis la dualidad Sí, soy judío (afirmación), pero soy un ciudadano norteamericano (conector adversativo). La preeminencia de lo segundo sobre lo primero, de la marca que impone el estado por sobre la que impone la tradición y la identidad cultural, no es nueva y recorre la historia de la literatura y de la política desde la célebre obra de Sófocles, Antígona, que pone en discusión la preeminencia de la ley de los hombres por sobre la ley tradicional ${ }^{17}$. Esto implica, dentro de esta sociedad en particular, un solapado totalitarismo: el Estado no puede negar la naturaleza del individuo (Magris, 2008, p. 40 y sigs.).

Este proceso podría encontrar en EE.UU. el espacio y las condiciones ideales para desarrollarse plenamente, pero para llevar a cabo no un genocidio o un exterminio sino algo mucho más sutil y, acaso, más efectivo: la desintegración de una identidad dentro de un espacio y de una población sumamente amplios. Es singular que Hannah Arendt considere que los fascismos no son auténticos totalitarismos en cuanto no han llevado a la práctica un genocidio (es decir, un exterminio planificado) de sus adversarios (Arendt, 1999, pp. 390-391). Y en el caso del nazismo, que no haya llevado adelante una auténtica política genocida hasta haber ampliado territorios y población en la medida suficiente 16 "Me opongo con todas mis fuerzas al trato que les dan [los nazis a los judíos], de la misma manera que se opone el coronel
Lindbergh. Sin embargo, ¿cómo será posible paliar el cruel destino que les ha sobrevenido en su propia tierra si nuestro gran país
entra en guerra con quienes los atormentan? [...] Sí, soy judío, y como tal sus sufrimientos me afectan en lo más hondo, como si
fuesen los de mi familia. Pero soy un ciudadano norteamericano, amigos míos -el público volvió a aplaudir- [...] y por ello os pregunto:
¿cómo se aliviaría mi dolor si Norteamérica entrara ahora en la guerra y, junto con los hijos de nuestras familias protestantes y los de
nuestras familias católicas, los hijos de nuestras familias judías fueran a luchar y morir por decenas de miles en el sangriento campo
de batalla europeo? [...]"
"-Está volviendo kosher a Lindbergh, legitimándolo -replicó Alvin-. Lo legitima para los gentiles. [...] ¿No te das cuenta, tío Herman, de
lo que ha conseguido que haga el gran Bengelsdorf? ¡Acaba de garantizar la derrota de Roosevelt!" (Roth, 2005b, pp. 52-54)

${ }^{17}$ Esto es particularmente intenso en una sociedad como la norteamericana, que ha dado pensadores como Henry Thoreau, que considera saludable, lógica y natural la supremacía del individuo por sobre el estado. 
para que semejantes políticas pudieran ser ejecutadas. Sin embargo, si repensamos el concepto de "exterminio", si le damos una interpretación, si se quiere, más cultural que física, el proceso que describe Roth es esencialmente totalitario: es el exterminio cultural de los judíos, devorados y asimilados (empleando un neologismo similar al de Roth) americaning (en lugar de koshering) "americanizando" a los judíos. La lógica de este proceso es, en cierto modo, muy "americana", ya que el estado ejercería violencia efectiva sólo en casos puntuales.

Este "narcicismo" americano es continuamente reforzado por la espectacularidad hollywoodense de la que se rodea Lindbergh, con sus trajes de aviador y sus aviones modernos o el legendario Spirit of Saint Louis (una referencia más al Volksgeist americano) con el cual cruzó el Atlántico y llevó adelante su hazaña. Theodor Adorno, por su parte, hace una lectura freudiana de este tipo de narcisismo nacional, hermano de la locura y de la banalidad, al que ve como uno de los ejes centrales del nazismo:

En el aspecto subjetivo, en la psique de las personas, el nacionalsocialismo elevó hasta lo inverosímil el narcisismo colectivo o, dicho de otro modo, la vanidad nacional. Las mociones pulsionales narcisistas de los individuos a los que un mundo endurecido promete cada vez menos satisfacciones y que continúan perviviendo mientras la civilización les niega tantas cosas, encuentran una satisfacción sustitutiva en la identificación con el todo. [...] Pero [...] la identificación y el narcisismo colectivo no fueron destruidos, sino que perviven de forma secreta, latente, inconsciente y, por tanto, con redoblado poder [...] (Adorno, 2005, pp. 62-63)

En un contexto como en el que Roth ubica su novela, o bien, en su mismo contexto de enunciación, este narcisismo se acrecienta precisamente como arma o recurso para enfrentar la angustia de un mundo amenazante (el peligro de una invasión en un caso, el del terrorismo en el otro). No es asombroso entonces que este proceso sea esencialmente "banal" y tenga como secuela la intolerancia a lo diferente.

Como en muchas obras logradas, The plot against America contiene una imagen que sintetiza todo este proceso. El totalitarismo, el Just Folks, la persecución a los judíos y, lo que podríamos llamar, la pérdida del paraíso aparecen articulados en una imagen que es, también, un sueño, una pesadilla dentro de la pesadilla. En él, Philip niño sueña con su sello postal favorito, que representa una estampilla postal de 1 centavo con un paisaje del parque nacional Yosemite. Este sello postal aparece como la síntesis de una identidad que aparece perturbada: sobre ese paisaje, sugestivamente verde, Philip ve una esvástica nazi. ${ }^{18}$.

El sueño se impone como imagen y verdad, y se convierte en el centro simbólico de la novela. La sintaxis que conforma, su "puesta en escena", es altamente efectiva: sobre un paisaje típicamente norteamericano, con todo su contenido mítico de naturaleza y libertad, un signo de la comunicación

18 Los editores seleccionarán precisamente esta imagen del sueño para el arte de tapa del libro. Pero en distintas ediciones norteamericanas posteriores, los editores modificaron la tapa del libro, reemplazando la esvástica por una simple equis (X) negra. Más allá de que probablemente el sentido haya sido el no exhibir públicamente un signo tan inequívoco, entendemos que esta versión distorsiona, o al menos no refleja, el contenido dramático de la tapa original. 
se transforma en símbolo del terror presente y futuro. Imagen que condensa la memoria, lo actual y el porvenir, el sueño del pequeño Philip aparece como la eternización del terror, su instauración definitiva, del que no se encuentran a salvo, ni siquiera, sus atesorados sellos postales, su bien más valioso. Este símbolo aparece, incluso, como eje de toda fragmentación, como destino de toda estigmatización. Transformarlo en una imagen onírica es hacerlo tan específicamente real como atemporal, ya que de ese modo escapa de todo lenguaje, de toda acción que lo refuerce o niegue. El mal está allí, y debe dividir para reinar. Y los inocentes sellos postales son sus mensajeros.

\section{Articulaciones entre la historia documental y la historia ficcional}

El plan general de la novela estructura el devenir como si hubiera existido solamente un impasse de poco más de un año, y las batallas de Guadalcanal o Pearl Harbour hubieran sucedido "desfasadas" cronológicamente, sin mayor detalle acerca de su desarrollo, y como si éste no fuera afectado por ese "desfasaje". Por tanto, la ucronía implica la construcción no de un mundo exclusivamente alternativo sino sobre todo altamente familiar, de tal modo, incluso, de volverlo (según la lógica freudiana) siniestro para el receptor. Esta característica de "siniestro" (en el sentido de Heimlich-Unheimlich) ${ }^{19}$ adquiere la forma de un intervalo dentro del flujo de la historia, un intervalo que no evita su final "feliz" (el triunfo aliado y la derrota del nazismo), pero que se plantea como una suerte de "burbuja ucrónica" dentro de la Historia que él mismo se ocupa de documentar. Por tanto, no es una mónada, como las célebres ucronías de Philip Dick o Norman Spinrad, sino precisamente una pesadilla hecha realidad, que se hace dueña de un tiempo y un lugar específicos. Esto hace que la ucronía en Roth no tenga una entidad metafísica definida, y que no podamos considerarla una obra de literatura fantástica o de Science Fiction. La construcción de esta ucronía es esencialmente "epistemológica" y se basa en la historia y en los modos en que ésta es narrada.

Esta "burbuja ucrónica", que suspende la historia factual por un lapso lo suficientemente extenso como para que los desarrollos de la historia alternativa adquieran esta dimensión siniestra, proyecta sentido en dos direcciones:

- Hacia adentro, esta burbuja se sustenta en la visión de un narrador auto-homo-diegético, que asume una "autobiografía ficcional del autor", en la cual no podemos deslindar completamente los componentes estrictamente ficcionales de los biográficos.

- Hacia afuera, provoca un "retraso" o suspensión momentánea en el desarrollo histórico. Lo que queda después del deus ex machina del final es la imagen de una pesadilla de la que la Historia (la de ese mundo, pero también la del nuestro) no puede despertarse.

Esta construcción epistemológica adquiere sentido sobre todo en el Apéndice final, cuando el autor detalla, a partir de datos documentales de la historia no ficcional, su lectura de lo que efectivamente sucedió a partir de una cronología de los personajes principales (los grandes actores históricos). Lo que no debemos dejar de observar es que esta lectura es, también, en cierto modo "ficcional", en

\footnotetext{
19 Según su célebre ensayo, "Lo siniestro", Freud ubica la categoría de lo siniestro en el ámbito de la recepción, a partir de considerar un suceso como "familiar" o "no familiar" (Heimlich - Unheimlich). Esta "familiaridad" (por ejemplo, la figura de Lindbergh en un contexto histórico común) adquiere, en cambio, matices monstruosos cuando se encuentra desfasada en tiempo, cuando lo "esperado" se vuelve inesperado sin perder su verosimilitud.
} 
cuanto implica un recorte específico en la lectura de estos acontecimientos. Siguiendo a Ricoeur y a White, este uso de la narrativa tiende a asimilarla a la categoría del discurso simbólico (White, 1992, pp. 69-70). Esto se traduce en una "imagen" a comprender de la Historia. Podríamos agregar: una imagen dialéctica, en cuanto es síntesis transitoria y constituye el "contenido" de esta forma narrativa singular.

El modo en que este Apéndice sincroniza la ficción depende necesariamente de la "lectura" de los acontecimientos que hace el autor. Por lo pronto, este apéndice, junto con la forma en que se desarrolla el final de la novela (que al desaparecer Lindbergh lleva a la intervención de EE.UU. en la guerra, curiosamente, "una vez más" gracias al error estratégico de los japoneses de atacar Pearl Harbour $^{20}$ ), presupone que una victoria aliada en la Segunda Guerra Mundial hubiese sido imposible sin el aporte esencialmente industrial de Norteamérica. Esta lectura de la historia, que cuenta con una aceptación más bien amplia, no es excluyente de otras. En general, los historiadores de la ex Unión Soviética, por el contrario, sin negar la importancia de este aporte, consideran como pieza fundamental en la derrota alemana el sacrificio y la lucha del pueblo ruso, sobre todo en la famosa batalla de Stalingrado (curiosamente, Roth "hace" que en la ucronía, la URSS pierda esta batalla). Esta forma de pensar la historia es sostenida por el autor como "la historia" real; por tanto, todo el desarrollo y la interpretación de la ficción debe ser leída a partir de este contexto que parte de un relato específico de la historia y, por tanto, determina la naturaleza de la ficción.

Por si fuera poco, Roth incluye al final dos textos: uno de Lindbergh, su discurso del 11 de septiembre de 1941 en el comité de América Primero ${ }^{21}$, con fuertes comentarios ya no sólo aislacionistas sino incluso racistas, y constituye el hipotexto a partir del cual el autor elabora los discursos y comentarios ante la prensa que hará el presidente en la ficción, del cual citamos un fragmento a modo de ejemplo: "Instead of agitating for war, the Jewish groups in the country should be opposing it in every possible way for they will be among the first to feel its consequences" (Roth, 2005a, p. 387) ${ }^{22}$. El otro es un extracto de una biografía sobre Lindbergh, escrita por A. Scott Berg, de 1998, en donde el autor destaca la convicción que Lindbergh tenía de que era la Unión Soviética el verdadero enemigo, a quien consideraba esencialmente maligna, y que, detrás de ella, aguardaban "el mongol, el persa y el moro" (Roth, 2005b, p. 428).

Todo este material, quizás exagerado en volumen, responde a una obsesión concreta por la historia. Hayden White ve en la novela de Roth una preocupación continua por la documentación de la

${ }^{20}$ Efectivamente, suele considerarse al ataque japonés sobre la base norteamericana de Pearl Harbour como un error estratégico, ya que desde el punto de vista de la lógica militar, el Imperio japonés podría haber continuado expandiéndose a costa de los imperios francés, holandés e inglés, sin contar con una resistencia apreciable, y sin la necesidad de desafiar a Norteamérica. EE.UU., por otro lado, no hubiese estado en condiciones de intervenir concretamente en la Guerra del Pacífico, al carecer de una excusa concreta. En general, se considera que esta decisión se tomó más a partir de un criterio de prestigio militar y político, y como parte de una rivalidad interna entre las fuerzas armadas de Japón (en donde la marina era, en gran medida pro-norteamericana, y el ejército, no; la fuerza aérea, por su parte, dependía o bien del comando terrestre o del naval). De hecho, el almirante Yamamoto, comandante en jefe de la Armada, ante la decisión tomada desde el gobierno (en manos del Ejército) de iniciar el conflicto, opta por un ataque sorpresa a Pearl Harbour con la esperanza de reducir el poder aeronaval norteamericano. El éxito será sólo temporal y relativo, dado que en dicho ataque no se vieron afectados los portaaviones norteamericanos. Fuente: AA.VV. (1981). Historia de la Aviación, T.3. Buenos Aires: Viscontea. (pp. 580-583)

${ }^{21}$ El original de este texto puede encontrarse en la dirección: www.pbs.org/vgbh/amex/lindbergh/filmmore/reference/primary/ desmoinesspeech.html

22 "En vez de agitar las conciencias para entrar en guerra, los grupos judíos de este país deberían oponerse de todas las maneras posibles, pues ellos figurarán entre los primeros en sufrir sus consecuencias” (Roth, 2005b, p. 424). 
historia (White, 2010, pp. 176-178). Un rasgo de The Plot against America es la necesidad del autor de suplementar la historia con materiales personales (en gran parte autobiográficos) como una forma de articular el pasado (los hechos de la segunda guerra mundial modificados) con las preocupaciones éticas del presente, en particular desde la focalización del autor (judío y norteamericano).

Me parece que Roth está en la línea directa de Scott, Dickens y Balzac en su creencia de que se debe atender a la historia como proveyendo los hechos que cualquier ideología política debe confrontar si ha de ser contada como realista. El hábil entretejido de Roth de memorias históricas con memorias personales y etnoculturales, tradiciones orales, periodismo, etc., lo convierte en un comentador brillantemente pertinente del "presente" de Occidente. [...] él [Roth] deja bastante claro qué es "historia" y que es "ficción imaginativa" en todas sus obras, y más aún en The plot against America, donde incluso anexa una cronología de "lo que realmente sucedió" frente a la cual medir la extensión de su propia inventiva en el cuerpo principal "literario" del texto. (White, 2010, p. 176)

Roth considera que lo histórico y lo ficcional pueden mezclarse para propósitos literarios, pero que no deben confundirse jamás, puesto que en él predomina el cronista del mundo actual. De ahí su preocupación por que no olvidemos que estamos ante una ficción, pero a su vez, que podamos compararla "materialmente" con la historia, tal como es aceptada al momento de la enunciación de la novela.

Esta "comparación" posee otro aspecto esencial: el cómo es vista la historia desde el interior de la "constelación". La historia aparece implicada en la vida cotidiana de los hombres comunes, ya no de las grandes figuras de la historia. Roth, a partir del personaje de su padre, elabora este concepto en la propia novela:

My father would try to find an hour each week to catch a complete show, and when he did, he'd recount over dinner what he'd seen and whom. Tojo. Pétain. Batista. De Valera. Arias. Quezon. Camacho Litvinov. Zhukov. Hull. Welles. Jarriman. Dies. Heydrich. Blum. Quisling. Gandhi. Rommel. Mountbatten. King George. La Guardia. Franco. Pope Pius. And that was but an abbreviated list of the tremendous cast of newsreel characters prominent in events that my father told us we would one day remember as history worthy of passing on to our own children.

"Because what's history?" he asked rhetorically when he was in his expansive dinnertime instructional mode. "History is everything that happens everywhere. Even here in Newark. Even here on Summit Avenue. Even what happens in his house to an ordinary man -that'll be history too someday" (Roth, 2005a, p. 180) ${ }^{23}$

\footnotetext{
23 "Mi padre procuraba encontrar una hora libre cada semana para ver un programa completo (de noticias, en el cine), y cuando lo conseguía, durante la cena nos contaba qué y a quiénes había visto. Tojo. Pétain. Batista. De Valera. Arias. Quezon. Camacho. Litvinov. Zhukov. Hull. Welles. Jarriman. Dies. Heydrich. Blum. Quisling. Gandhi. Rommel. Mountbatten. El rey Jorge. La Guardia. Franco. El papa Pío. Y eso no era más que una lista abreviada del enorme reparto de los personajes importantes de noticiario en acontecimientos que, según mi padre, un día recordaríamos como historia digna de ser transmitida a nuestros propios hijos".

"- Porque ¿qué es la historia? - preguntaba retóricamente cuando estaba en vena instructiva y comunicativa después de cenar-. La historia es cuanto sucede en todas partes. Incluso aquí en Newark. Incluso aquí, en la avenida Summit. Incluso lo que le ocurre en esta casa a un hombre normal... Eso también será historia algún dia". (Roth, 2005b, pp. 202-203)
} 
La enumeración es elocuente: todos los actantes importantes de la historia contemporánea (la factual y la ficcional) aparecen referenciados, incluso algunos no expresamente políticos. El aparente desorden de la lista no hace más que reforzar un concepto de historia como flujo de acontecimientos en busca de una forma. Es el reparto de la obra. El segundo párrafo, acaso, nos da la respuesta de cómo esa forma se hace "sólida": La Historia es cuanto sucede en todas partes, y en particular, a la gente común. Algún día, esa historia se haría digna de ser transmitida a nuestros hijos, sería digna de ser convertida en relato. Esta dignidad de narrar desde el espacio íntimo es lo que, en definitiva, devuelve al hombre su fe en la historia.

Evidentemente, aun cuando no haya formado parte expresamente del plan del autor, la historia contemporánea- no es ajena a la conformación de la novela. Escrita durante las presidencias de George Bush hijo, el rol de la institución presidencial en los destinos de EE.UU. aparece significativamente criticado con dureza, crítica que efectivamente resuena en el presente. En el fragmento siguiente, observamos como Roth proyecta, a través de la figura de Fiorello La Guardia el vínculo entre texto y contexto: la adoración de la figura presidencial en Estados Unidos, adoración que lleva a aceptar, incluso, medidas fuertemente impopulares. De este modo, implícitamente, Roth vincula a Lindbergh con la política de George Bush hijo. Este culto a la figura presidencial, que puede derivar en situaciones dignas de un régimen totalitario (en el contexto, la situación de los presos de Guantánamo, por ejemplo), es expresamente criticado por Roth, aunque luego, en una entrevista que otorgó a la periodista del diario La Nación de Buenos Aires Juana Libedinsky poco después de la edición en español de la novela, el escritor se distancia de este tipo de interpretaciones contextuales. Reproducimos a continuación parte de esta entrevista:

La Nación, Lunes 5 de diciembre de 2005. Entrevista de Juana Libedinsky:

\section{-Su libro fue interpretado por la izquierda como una crítica al gobierno de Bush, como un paralelismo velado a su gobierno. ¿Fue ésa su intención?}

-Le voy a contar un cuento: había un carpintero que hacía unas sillas muy lindas. Un día, al volver del trabajo, ve por la ventana que un vecino le está partiendo una de sus sillas a la mujer por la cabeza. Sigue caminando y ve que otro está cortando la silla en trozos pequeñitos y tirándola a la chimenea para calentarse. Obviamente, él construyó las sillas para que la gente se sentara, pero, una vez que fueron compradas, sabe que cada dueño las va a usar según su necesidad. Bueno, yo no escribí mi libro para pegarle a Bush en la cabeza, pero cada uno puede usarlo para lo que se le plazca. No es un tema mío, y de cualquier manera el 90 por ciento de las interpretaciones siempre son erradas. Cuando a un libro se lo saca de contexto y se lo usa para una agenda política, ¿qué se le va a hacer? Es algo que viene de siempre, en Praga el régimen prohibió a Kafka, por ejemplo, ¿y qué tenía que ver Kafka con la invasión soviética de Checoslovaquia? Yo empecé mi libro antes de que Bush fuese a la Casa Blanca, antes del 11 de septiembre [de 2001] Quería escribir sobre 1942, recrear ese momento y explorar las posibilidades que afortunadamente nunca se materializaron. 
Al preguntarle sobre si consideraba posible que la ficción hubiese sido realidad, Roth responde de manera elocuente:

\section{¿CCree que habría sido posible un Lindbergh presidente en los Estados Unidos?}

-No, iporque no pasó! Pero fue una suerte que los republicanos no hayan tenido la viveza política de nombrar a un Lindbergh, porque definitivamente le habría ganado a Roosevelt en las elecciones. En cambio nombraron a un moderado, un intervencionista e internacionalista al igual que Roosevelt, y así no había verdadera competencia. [...]. Después de Roosevelt los republicanos hicieron una enmienda en la Constitución para que un presidente sólo pueda estar durante dos términos. ¡Y eso fue muy bueno porque eliminó el riesgo de tener a Reagan o a Bush tres veces!

Roth no ve a lo posible como parte de la realidad. De ahí el énfasis en su respuesta. Tal como señalaba White, la visión del autor es esencialmente "realista", de algún modo, decimonónicamente realista. Lejos de lo fantástico, Roth vive en un cosmos newtoniano, en donde el tiempo, si es alterado, es para convertirse en fábula.

\section{Conclusión: Ucronía y Pesadilla Histórica}

Podríamos decir que The plot against America es la descripción de una cierta "bipolaridad" política norteamericana, que la impulsa tanto en lo exterior como en lo interior hacia actitudes paradójicas. Visto de este modo, este mundo posible adquiere sentido en cuanto imagen de esta paradoja, cuya resolución es transitoria. Si existe algún vínculo deliberado (asumimos que siempre existen vínculos no conscientes) entre el pensamiento del autor y el momento en que fue escrita la novela (durante el gobierno de George Bush hijo y en medio de su reelección en 2004), podemos hallarlo en esta paradoja: democracia y totalitarismo reunidos en la misma intención de proteger los intereses de la nación. La preponderancia de uno sobre otro se manifiesta en la forma de la política. Desde ya, asumimos que la forma es un contenido en sí.

La novela de Roth resulta entonces una suerte de puesta en abismo de profundas contradicciones vigentes (tan vigentes ahora como en el tiempo del enunciado de la novela o el tiempo de su elaboración) en el mismo seno de la política y la historia norteamericanas. Si un político, como el que en la ficción fue Charles Lindbergh, o un industrial de profunda influencia en la política como Henry Ford, hubieran podido orientar a su nación hacia un camino absolutamente opuesto al que siguió, no es sólo porque un hecho menor podría haber sucedido o no realmente (si Lindbergh, acaso, hubiera aceptado o no una candidatura). En ese acto "menor" se condensa toda la historia previa de un país. No existen actos individuales, sobre todo, pero no solamente, en la política. Cada decisión es esencialmente colectiva, en cuanto es suma de una historia, historia de la que han participado infinidad de actores. El vértigo de pensar estos actos nos permite ver, no obstante, en qué medida nada es insignificante, al menos en la historia. Esto no se limita a los grandes actantes de la historia, a Roosevelt o a Ford, sino también incluye a los actantes individuales, aquellos que, según el padre 
de Roth en la ficción, hacen la historia aquí y ahora. Emigrar o no emigrar a Canadá; unirse o no a las fuerzas aliadas; apoyar o no al rabino Bengelsdorf; huir o no con un álbum de estampillas; todos son actos prefigurados por la historia. Este es uno de los sentidos de la autobiografía ficcional: en cada acto o decisión (del padre, de Alvin, de Evelyn, del propio Roth niño) está contenida también la Historia (la factual y la ficcional, la propia y la nuestra). ¿Qué hubiéramos hecho dentro de esa pesadilla? Que equivale a preguntar ¿qué haremos ahora? Todo depende de muy poco y, casi siempre, comprendemos el valor de esos hechos insignificantes sólo cuando se cargan con el peso del pasado. En esto consiste la universalidad de la novela que nos ocupó hasta aquí: no sólo el problema judío en EE.UU., o la política norteamericana; mucho menos, la Segunda Guerra Mundial. Es universal que todo acto genere historia, incluso (acaso, sobre todo) cuando no merezca un lugar entre los libros de los historiadores. Estará allí, como los sueños o las pesadillas, dando vueltas entre la gente común, esperando un acontecimiento para irrumpir entre nosotros.

\section{Referencias bibliográficas}

\section{Primaria:}

ROTH, Philip. (2005a). The plot against America. New York: Vintage.

----. (2005b). La conjura contra América. Barcelona: Mondadori.

\section{Secundaria:}

AA.VV. (1981). Historia de la Aviación, T.3. Buenos Aires: Viscontea. (pp. 580-583)

ADORNO, Theodor. (2005). Ensayos sobre la propaganda fascista. Buenos Aires: Paradiso.

ARENDT, Hannah. (1999). Los orígenes del totalitarismo. Madrid: Taurus.

DEL PERCIO, Daniel. (2012). Cuando la ficción nos hace promesas: una aproximación teórica a los vínculos entre el relato histórico y la literatura utópica. En Montezanti, M. [Edit.]. Actas de las X Jornadas de Literatura Comparada. La Plata UNLP. Sitio web: http://xjornadaslc.fahce.unlp. edu.arl

DOLEZEL, Lubomir. (1998). Heterocosmica. Fiction and Possible Worlds. Baltimore: The Johns Hopkins University Press.

FERGUSON, Niall. (1998). Historia virtual. Madrid_Taurus.

FERRATER MORA, J. (2001). Diccionario de filosofía (Q-Z). Madrid: Ariel.

FREUD, Sigmund. Lo siniestro. (1997). En Obras completas, T. 18. Buenos Aires: Losada.

JAY, Paul (1993). El Ser y el Texto. La autobiografía, del Romanticismo a la Posmodernidad. Madrid: Megazul.

MAGRIS, Claudio. (2008). Literatura y Derecho ante la ley. Madrid: Sexto Piso.

NANCY, Jean-Luc. (2008). Tres fragmentos sobre nihilismo y política. En Esposito, Roberto; Galli, Carlo; y Vitiello, Vincenzo [comp.]. Nihilismo y política. Buenos Aires: Manantial.

REIS, Carlos, y Lopes, Cristina. (1995). Diccionario de Narratología. Salamanca: Colegio de España. 
RICOEUR, Paul. (1999). Historia y narratividad. Barcelona: Paidós.

---. (2007). Tiempo y Narración: configuración del tiempo en el relato histórico. T. 1. México: Siglo XXI.

----. (2007). Tiempo y Narración: configuración del tiempo en el relato de ficción. T. 2. México: Siglo XXI.

----. (2007). Tiempo y Narración: El tiempo narrado. T. 3. México, Siglo XXI.

WHITE, Hayden. (1992). El contenido de la forma. Narrativa, discurso y representación histórica. Barcelona: Paidós.

---. (2010). Ficción histórica, historia ficcional y realidad histórica. Buenos Aires: Prometeo. 